\title{
Life cycle and host range of Phycita sp. rejected for biological control of prickly acacia in Australia
}

\author{
K. Dhileepan ${ }^{1}$, C. J. Lockett ${ }^{1}$, A. Balu², S. Murugesan², D. J. Perovic ${ }^{1, \dagger}$ \& D. B. J. Taylor ${ }^{1}$ \\ 1 Department of Agriculture and Fisheries, Ecosciences Precinct, Biosecurity Queensland, Brisbane, QLD, Australia \\ 2 Institute of Forest Genetics and Tree Breeding, Coimbatore, India
}

\section{Keywords}

biological control, field host range, host specificity, leaf webber, non-target risk, Phycitinae

\section{Correspondence \\ Kunjithapatham Dhileepan (corresponding author), Department of Agriculture and Fisheries, Biosecurity Queensland, Ecosciences Precinct, Dutton Park, QLD 4102, Australia.E-mail: k.dhileepan@qld.gov.au \\ †Current address: Fujian Agriculture and Forestry University Fuzhou, Fujian, China \\ Received: October 9, 2014; accepted: February 25, 2015.}

doi: $10.1111 /$ jen. 12220

\begin{abstract}
Prickly acacia (Vachellia nilotica subsp. indica), a native of the Indian subcontinent, is a serious weed of the grazing areas of northern Australia and is a target for classical biological control. Native range surveys in India identified a leaf webber, Phycita sp. (Lepidoptera: Pyralidae) as a prospective biological control agent for prickly acacia. In this study, we report the life cycle and host-specificity test results Phycita sp. and highlight the contradictory results between the no-choice tests in India and Australia and the field host range in India. In no-choice tests in India and Australia, Phycita sp. completed development on two of 11 and 16 of 27 non-target test plant species, respectively. Although Phycita sp. fed and completed development on two non-target test plant species (Vachellia planifrons and $V$. leucophloea) in no-choice tests in India, there was no evidence of the insect on the two non-target test plant species in the field. Our contention is that oviposition behaviour could be the key mechanism in host selection of Phycita sp., resulting in its incidence only on prickly acacia in India. This is supported by paired oviposition choice tests involving three test plant species (Acacia baileyana, A. mearnsii and A. deanei) in quarantine in Australia, where eggs were laid only on prickly acacia. However, in paired oviposition choice trials, only few eggs were laid, making the results unreliable. Although oviposition choice tests suggest that prickly acacia is the most preferred and natural host, difficulties in conducting choice oviposition tests with fully grown trees under quarantine conditions in Australia and the logistic difficulties of conducting open-field tests with fully grown native Australian plants in India have led to rejection of Phycita sp. as a potential biological control agent for prickly acacia in Australia.
\end{abstract}

\section{Introduction}

Prickly acacia, Vachellia nilotica subsp. indica (Benth.) Kyal. \& Boatwr. (previously known as Acacia nilotica subsp. indica), is a serious weed of the grazing areas of western Queensland and has the potential to spread throughout northern Australia (Mackey 1997; Kriticos et al. 2003; Dhileepan 2009). Prickly acacia infests over 7 million hectares of natural grasslands and over $2000 \mathrm{~km}$ of bore drains (artificial channels of permanent flowing water from artesian bores) in western Queensland (Mackey 1997).
Infestations also occur in the coastal regions of Queensland, in the Northern Territory and Western Australia (Mackey 1997). Prickly acacia infestations in Queensland cost primary producers Au\$ 9 million/year in lost pasture production (Dhileepan 2009). In such areas, prickly acacia forms impenetrable thorny thickets, competes with native pasture species, prevents the growth of native plants beneath the canopy, restricts stock access to watercourses and poses a threat to nearly 25 rare and threatened animal species and two endangered plant communities (Spies and March 2004). 
Vachellia nilotica (L.) P.J.H.Hurter \& Mabb is a multipurpose tree native to Africa, the Middle East and the Indian subcontinent (Dwivedi 1993). It is a polytypic species with nine recognized subspecies in its native range, each subspecies having a distinct geographic range (Brenan 1983). Three subspecies, $V$. nilotica subsp. indica (prickly acacia), $V$. nilotica subsp. cupressiformis (J.L. Stewart) Ali \& Faruqi and V. nilotica subsp. hemispherica Ali \& Faruqi, are native to India and Pakistan (Dwivedi 1993).

Prickly acacia was introduced from India into Australia in the late 1890s (Dhileepan 2009). It is the only subspecies of $V$. nilotica introduced into Australia. It is a large thorny tree growing up to $10 \mathrm{~m}$ high. Seedling recruitment in Australia is linked to rainfall pattern, and under favourable conditions, young plants attain maturity in 2-5 years. When mature, prickly acacia forms dense thorny thickets ( 900 plants/ha), and mature plants live for $c .40$ years. The trees have distinct flat sickle-shaped pods, each with $8-15$ seeds. A mature tree can produce up to 300000 seeds per year, and seeds, when buried in soil, can remain viable up to 7 years (Dhileepan 2009). Prickly acacia seedlings and juvenile trees are considered the best life stage to target for control (Kriticos et al. 1999). Simulated herbivory study suggests that prickly acacia seedlings are susceptible to defoliation and shoot damage (Dhileepan et al. 2009).

Biological control of prickly acacia in Australia was initiated in the early 1980s, with native range surveys conducted on $V$. nilotica subsp. indica in Pakistan (Mohyuddin 1986), on $V$. nilotica subsp. subalata (Vatke) Kyal. \& Boatwr. and $V$. nilotica subsp. leiocarpa (Brenan) Kyal. \& Boatwr. in Kenya (Marohasy 1992) and on $V$. nilotica subsp. kraussiana (Benth.) Kyal. \& Boatwr. in South Africa (Stals 1997). These surveys resulted in the introduction of two agents from Pakistan and four agents from South Africa and Kenya into Australia. Among them, only a seed-feeding bruchid Bruchidius sahlbergi Schilsky introduced from Pakistan and a leaf-feeding geometrid Chiasmia assimilis (Warren) introduced from Kenya and South Africa have become established (Dhileepan 2009). The impact of $B$. sahlbergi on prickly acacia has been insignificant (Radford et al. 2001), while C. assimilis has established only at coastal sites and not widely in the arid inland regions where the major infestations occur (Palmer et al. 2007). As a result, more effective biological control agents are needed for arid inland Australia.

Native range surveys were refocussed in India (Dhileepan et al. 2010, 2013), where the invasive Australian prickly acacia populations (subsp. indica) originated (Wardill et al. 2005). Areas climatically similar to the arid inland regions of northern Australia in India were targeted (Dhileepan et al. 2006). Based on field host range, geographic range and damage potential, a leaf webber, Phycita sp. (Lepidoptera: Pyralidae), was prioritized for detailed host-specificity tests (Dhileepan et al. 2013). No-choice larval development tests were conducted in India and Australia to determine the fundamental host range (species on which the agent can complete its life cycle) of Phycita sp. As Phycita sp. larvae completed development on several non-target plants under no-choice conditions, field host range studies in India and oviposition tests in Australia were also conducted to try and predict the realized host range (plant species that will support the agent population in the field) of the moth. In this study, we report the life cycle, fundamental host range in India and Australia and field host range in India for Phycita sp., a prospective biological control agent for prickly acacia in Australia.

\section{Materials and Methods}

\section{Study species}

Members of the Phycitinae have been exploited as weed biological control agents (e.g. Dodd 1940; Coombs et al. 2004), including species in the genus Phycita (Sakalasooriya et al. 2000). The majority of species in the genus Phycita for which host records are available are crop pests (e.g. Brues 1936; Butani 1970; Ponnuswami 1971; Aina 1983; Ram and Pathak 1987; Rani and Sridhar 2002). Host records for other species are not available.

The leaf webber collected on prickly acacia in India was initially identified as Phycita leuconeurella Ragonot (syn. Hyalospila leuconeurella Ragonot) by Dr George Mathew at the Kerala Forest Research Institute in India. A literature search found that $P$. leuconeurella has been reported as a pest of mango (Mangifera indica L.) in India (Ponnuswami 1971) and a pest of cashew (Anacardium accidentale L.) in Sri Lanka (Hutson 1939). However, no larval development occurred on either mango or cashew under no-choice conditions in India, suggesting that the species is not P. leuconeurella. Specimens were then sent to the Natural History Museum (NHM) in the United Kingdom for identification. As the species status of the Phycita sp. could not be confirmed by NHM, we treated the species as Phycita sp.

In surveys conducted in India (Dhileepan et al. 2013), Phycita sp. was found only in southern India (Tamil Nadu and Karnataka) and not in north-west 
India (Rajasthan and Gujarat). In Tamil Nadu and Karnataka, Phycita sp. caused severe defoliation in prickly acacia trees throughout the year. Phycita sp. was observed in the majority of the survey sites $(76 \%)$ in Tamil Nadu and Karnataka throughout the year, with higher incidences from September to January, coinciding with the north-east monsoon. Phycita $\mathrm{sp}$. was found on all three subspecies of $V$. nilotica (subsp. indica, subsp. cupressiformis and subsp. tomento$s a)$, but more often on larger trees than on juvenile plants. Females lay eggs on prickly acacia trees and the emerging neonate larvae construct a leaf web by tying the leaves. The larvae feed and complete development within the leaf web on the same host tree. Thus, Phycita sp. behaves more like leaf miners or gall insects where the adult moths choose the host tree for the larvae.

\section{Insect cultures}

A colony of Phycita sp. was established in an insectary at the Institute of Forest Genetics and Tree Breeding (IFGTB), Coimbatore, Tamil Nadu, in southern India in March 2010, using field-collected larvae and pupae from Coimbatore, Pollachi, Tiruchirappalli, Madurai and Thanjavur regions in Tamil Nadu, India. The colony was maintained either on cut foliage of prickly acacia held in glass jars $(30 \mathrm{~cm} \times 15 \mathrm{~cm})$ with the cut ends of the shoots inserted in a glass vial with tap water and the mouth of the glass jar covered with white muslin cloth, or on potted prickly acacia plants in insectproof cages $(60 \times 60 \times 10 \mathrm{~cm})$. Adults were fed on diluted honey. Newly emerged moths were released directly into glass oviposition containers with prickly acacia cut foliage for egg laying. Newly emerged larvae collected from oviposition containers were used in the life cycle and host-specificity tests in India.

Field-collected Phycita sp. larvae and pupae from Coimbatore, Pollachi, Tiruchirappalli, Madurai and Thanjavur regions in Tamil Nadu, India, were exported to a quarantine facility at the Ecosciences Precinct (ESP), Brisbane, Australia, in January 2011. A colony of Phycita sp. was maintained in insect-proof cages $(90 \times 80 \times 75 \mathrm{~cm})$ on both whole plants and cut foliage of prickly acacia in a quarantine glasshouse $\left(22-27^{\circ} \mathrm{C} ; 65 \% \mathrm{RH}\right.$ and natural photoperiod). Newly emerged moths were either released directly into insect-proof cages containing potted prickly acacia plants or were placed in pairs in glass oviposition containers with prickly acacia cut foliage for egg laying. Food (sports drink containing water, carbohydrates and electrolytes; Gatorade ${ }^{\circledR}$; PepsiCo Australia, Chatswood, Australia) was supplied in 30-ml transparent plastic cups with a sponge as a wick to adults used in colony maintenance and in oviposition tests, to enhance egg production and adult longevity. Newly emerged larvae collected from oviposition containers were transferred onto potted prickly acacia plants in insect-proof cages for larval development and pupation. Pupae were collected from potted plants and kept in plastic containers for adult emergence. Newly emerged larvae and adults were used in all experiments.

\section{Life cycle}

The life cycle was studied using potted prickly acacia plants in a quarantine glasshouse at ESP under controlled climatic conditions (night temperature: $20^{\circ} \mathrm{C}$; day temperature: $27^{\circ} \mathrm{C}$; $\mathrm{RH} 65 \%$; and photoperiod: $12 \mathrm{~h}$ dark: $12 \mathrm{~h}$ light). Pairs of newly emerged and mating adults ( $\mathrm{n}=10$ pairs) were transferred on to potted prickly acacia plants enclosed in cylindrical transparent Perspex tubes $(34 \mathrm{~cm}$ high and $12 \mathrm{~cm}$ diameter) with an insect-proof gauze cap at the top and the bottom end of the tube inserted in to the pot. The adults were transferred onto a fresh plant each week. Adult longevity and pre-oviposition period were recorded together with the number of eggs laid per female per week and the duration of larval and pupal stages.

\section{Test plants}

The host-specificity test list comprising 74 plant species that was used for previous agents (e.g. Palmer et al. 2007) was revised (Dhileepan et al. 2014), based on recent taxonomic changes to Acacia sensu lato (Maslin 2001; Orchard and Maslin 2003; Kodela and Wilson 2006). The genus Acacia sensu lato, the largest genus (with over 950 endemic species) of flowering plants in Australia (Orchard and Wilson 2001), has recently been split into five genera: Acacia Mill., Vachellia Wright \& Arn., Senegalia Raf., Acaciella Britton $\&$ Rose and Mariosousa Seigler \& Ebinger (Orchard and Maslin 2003; Kodela and Wilson 2006). Within the tribe Acaciae, representatives of Vachellia (six species), Senegalia (three species) and Acacia (36 species) species were included in the test list. Representatives from subfamilies Mimosoideae (tribes Mimoseae and Ingeae), Caesalpinoideae (tribes Cesalpinieae, Cassieae and Detarieae), Faboideae (tribes Bossiaaeeae, Cercideae, Mirbellieae, Millettieae, Phaseoleae and Sophoreae) in the order Fabales and representatives of other closely related orders Malpighiales (Euphorbiaceae), Malvaes (family Malvaceae), Sapinales (family 
Anacardiaceae) and Piperales (family Piperaceae) were also included in the test plant list (Dhileepan et al. 2014). For Phycita sp., tests were completed only for 37 plant species (Table S1) and testing of the remaining test plants was not continued due to feeding and development on multiple non-target test plant species.

In India, 10 test plant species from the tribes Acaciae and Mimoseae (Table S1) that either co-occur with prickly acacia in India or are endemic to Australia (exported to India as seeds) were included in the no-choice tests. Two phylogenetically unrelated, but economically important plants, mango $(M$. indica) and cashew (A. occidentale) (both Anacardiaceae) were also included in the no-choice tests, as a Phycita species has been reported as a pest of both crops (Hutson 1939; Ponnuswami 1971). All test plants and prickly acacia used in host-specificity tests were grown in pots under direct sunlight.

In Australia, no-choice larval feeding tests for Phycita sp. were completed for only 28 test plant species (Table S1). These included two test plant species, $\mathrm{Va}$ chellia farnesiana (L.) Willd. and Acacia deanei (R. T. Baker) Welch, Coombs \& McGlynn, that were also tested in India. Testing of the remaining species was suspended due to non-target feeding and development on several test plant species. Instead, oviposition tests were conducted to predict the realized host range of Phycita sp. Test plant species used in host-specificity tests in Australia were sourced either as potted plants from nurseries or grown from seeds. The potted plants used in host-specificity tests were either grown or maintained in glasshouse $\left(27^{\circ} \mathrm{C}\right.$ day temperature, $22^{\circ} \mathrm{C}$ night temperature, $65 \%$ relative humidity and UV-excluded sunlight) or in greenhouse (under 50\% shade).

\section{Host-specificity tests}

\section{No-choice tests}

In India, no-choice tests were conducted on 12 potted plant species (including prickly acacia as control). Tests were conducted from June 2010 to March 2011 and from September 2011 to December 2011. Additional plants or cut foliage as bouquets (for $M$. indica) was added to cages, when required, and the larvae were allowed to move onto the fresh foliage by themselves. In each test, 10 unfed neonate larvae were placed on potted test plants within insect-proof cages placed outside under direct sun at IFGTB. There were five replicates for each test plant species. All inoculated test plants were monitored daily to determine the duration of larval and pupal stages and the proportion of larvae and pupae developing into pupae and adults, respectively.

In Australia, host-specificity testing commenced in June 2011 and was completed in December 2012. All tests were conducted in a temperature $\left(22-27^{\circ} \mathrm{C}\right)-$, light (14 h light: $10 \mathrm{~h}$ dark)- and humidity (60-70\% $\mathrm{RH}$ )-controlled quarantine insectary at the ESP in Brisbane, Queensland. The potential host range of Phycita sp. was evaluated initially using no-choice tests. Batches of test plants, predominantly seedlings or juveniles, were screened as they became available, and in each batch potted, prickly acacia plants were included as positive controls. Ten newly emerged larvae were placed on each potted test plant, as well as a prickly acacia control plant. Plants with larvae were placed in groups in insect-proof cages and were checked 2-3 times per week for evidence of larval feeding and webbing. Fresh test plants were added as required to feed developing larvae. When there was larval feeding, the duration of larval survival, proportion of larvae developing into pupae, pupal duration and proportion of pupae emerging as adults were recorded. A minimum of five replicates of each test plant was used.

\section{No-choice continuation trials}

To ascertain the suitability of non-target plant species to sustain continuous generations of Phycita sp., nochoice continuation trials were commenced in April 2012 under quarantine conditions in Australia. Three non-target test plant species, Acacia baileyana F.Muell., A. mearnsii De Wild. and A. irrorata Sieber ex Spreng., were chosen for no-choice continuation trials, as they supported higher survival and development of Phycita sp. larvae to adults in the no-choice larval feeding trials. Trials were conducted using potted test and control plants placed separately in insect-proof cages $(90 \times 80 \times 75 \mathrm{~cm})$. Each test was replicated a minimum of three times and commenced with the placement of 60 newly emerged first instar larvae onto both test (A. baileyana, $A$. mearnsii or $A$. irrorata) and control (prickly acacia) plants. Additional plants were added to cages, as required, to feed developing larvae until pupation. The total number of adults emerging per test cage was recorded, together with the development period (in days) from first instar larva to adult. When sufficient numbers of males and females were collected together, pairs were placed in oviposition containers to allow mating and oviposition. The numbers of eggs laid by each female were recorded. Newly hatched larvae were then used to set up subsequent generations on the same test plant species. Individual test replicates were continued for a maximum of three 
subsequent generations, if sufficient eggs and larvae were produced.

\section{Choice oviposition tests}

All oviposition tests were conducted in Australia under quarantine conditions. The initial oviposition trial was a paired-choice test simultaneously exposing prickly acacia and a non-target plant (A. mearnsii or $A$. deanei). A single pair of adults was placed in a cage $(90 \times 80 \times 75 \mathrm{~cm})$ with the two plants (one prickly acacia and one non-target plant), and the number of eggs laid was counted after 1 week. No non-target egg laying was observed through six replicates with A. deanei and through three replicates with A. mearnsii. However, egg laying was very erratic, and in the majority of replicates, no eggs were laid on any plant, thus making the results unreliable and statistically difficult to draw any conclusion.

We hypothesized that the initial trial had failed to give clear results because plants were an unacceptable size for females. To test this, we ran paired-choice tests with two prickly acacia plants: one the size used in the initial trial $(\sim 30 \mathrm{~cm}$ tall $)$ and another a larger $(\sim 60-90 \mathrm{~cm}$ tall $)$ plant in insect-proof cages $(90 \times 80 \times 75 \mathrm{~cm})$. These trials revealed a clear preference for larger plants. Preliminary trials also showed that the use of multiple pairs of adults (two females + two males per cage) that were pre-mated (pairs that were allowed to mate over a day before releasing them to the experimental oviposition cages) produced more consistent oviposition than using single pairs of adults and newly emerged adults.

Having established a more reliable method for conducting oviposition trials using larger plants, multiplechoice oviposition trials, exposing one prickly acacia plant together with four non-target species (A. baileyana, A. mearnsii, A. oshanesii F. Muell. \& Maiden and A. macradenia Benth,) in the large walk-in cage $(200 \mathrm{~cm} \times 200 \mathrm{~cm} \times 200 \mathrm{~cm})$, were conducted. Despite following the new procedure, and repeating three replicates, moths failed to lay eggs on any plant and all eggs were laid on the gauze walls of the cage. Hence, multiple-choice oviposition trials in large walk-in cages were discontinued.

Selected test plant species on which there was higher larval survival and development in no-choice tests (A. baileyana, A. mearnsii and A. deanei) were subjected to paired-choice oviposition tests (one test plant and one prickly acacia plant per cage) in insectproof cages $(90 \times 80 \times 75 \mathrm{~cm})$. Larger test plants ( $60-90 \mathrm{~cm}$ tall) were used with a minimum of two pairs of pre-mated, 1-day-old adults. There were seven replicates for paired-choice trials involving
A. mearnsii, six replicates for paired-choice trials involving $A$. deanei and three replicates for pairedchoice trials involving $A$. baileyana. Adults were left in the choice oviposition arena for 5 days and then the numbers of eggs laid on individual test plants and on the cage walls were counted a week later.

\section{Field host range - India}

In India, a total of 72 sites (64 sites in Tamil Nadu and eight sites in Karnataka) were surveyed at quarterly intervals from November 2008 to December 2011 (Dhileepan et al. 2013, Table S2). At each site, two or three research staff spent a minimum of $1 \mathrm{~h}$ surveying for insects. Incidence and severity of damage by Phycita sp. were recorded, along with plant age (seedling, juvenile tree or mature tree) and the subspecies of the $V$. nilotica (subsp. indica, subsp. cupressiformis and subsp. tomentosa) present. Among the survey sites, 13 had only subsp. indica, two had only subsp. cupressiformis, 51 sites had both subsp. indica and subsp. tomento$s a$, and six sites had both subsp. indica and subsp. cupressiformis (Table S2). On all visits, co-occurring vegetation (other Acacia, Vachellia and Senegalia species) was also surveyed for the presence of Phycita sp. larvae. At sites with juvenile and young plants, the entire plant canopy was surveyed, while at sites with mature trees, only branches accessible from the ground were sampled.

\section{Data analysis}

One-way anova was used to compare (i) the duration of larval and pupal survival, the proportion of larvae that developed into pupae and the proportion of pupae that developed into adults on various test plant species in no-choice larval feeding tests; (ii) the duration of larval development, the proportion of larvae that developed into pupae and adults and the number of eggs per female in no-choice continuation trials; and (iii) the number of eggs laid in choice oviposition tests. The data sets that did not meet underlying assumptions of normality and homogenous variances were analysed using Kruskal-Wallis test. The means were compared using Dunn's test. All results in the text are presented as means \pm standard error.

\section{Results}

\section{Life cycle}

Adult moths lived for $8.8 \pm 0.5$ days (range: 6 to 21 days) and laid eggs within 2-10 days of adult 
emergence. Females laid $78 \pm 8$ eggs (range: 55 to 350 eggs) during their life, on the leaves and stems of host plants, cage walls or the gauze covers on oviposition containers. Eggs hatched in 6 to 10 days and the newly emerged larvae fed almost immediately, tying leaves together with silk webs and forming tunnels as they matured. The larval stage lasted for $41 \pm 1.2$ days (range: $27-48$ days). Fully grown larvae pupated for $13 \pm 0.4$ days (range: 6-19 days) within the larval silk tunnel or in the soil. On prickly acacia, $80 \%$ of the neonate larvae became adults.

\section{Host-specificity tests}

\section{No-choice tests}

In no-choice trials in India, the duration of larval survival was significantly lower on the non-target plants than on the target weed $\left(\mathrm{F}_{11,44}=106.2, \mathrm{P}<0.001\right.$; fig. 1). The larvae completed development and became adults on only two non-target test plant species, Vachellia leucophloea (Roxb.) Maslin, Seigler \& Ebinger and $V$. planifrons Ragupathy, Seigler, Ebinger \& Maslin (fig. 1). However, on both non-target species, the proportion of larvae that developed into pupae $(V$. nilotica subsp. indica $=98 \%, \quad V$. planifrons $=52 \% ， \quad V$. leucophloea $=30 \% ; \quad \mathrm{F}_{2,12}=75.3$, $\mathrm{P}<0.001)$ and adults ( $V$. nilotica subsp. indica $=76 \%$, $V$. planifrons $=34 \%, \quad V$. leucophloea $=26 \% ; \quad \mathrm{F}_{2,12}=$ 16.9, $\mathrm{P}<0.001)$ was significantly lower than on the target weed (fig. 1). Larvae did not complete development on the other non-target test plant species tested (fig. 1).

In Australia, no-choice larval feeding and development tests were completed for 28 test plant species (Table S1). Non-target feeding and development through to adults occurred on 16 of the 27 non-target plant species (figs 2 and 3). The durations of larval survival (Kruskal-Wallis test, $H=174.93$; $\mathrm{P}<0.001$ ) and pupal survival (Kruskal-Wallis test, $H=89.32$; $\mathrm{P}<0.001)$ and the proportion of larvae that developed into pupae (Kruskal-Wallis test, $H=114.64$; $\mathrm{P}<0.001$ ) and adults (Kruskal-Wallis test. $H=80.47$; $\mathrm{P}<0.001)$ differed significantly between the test plant species (figs 2 and 3). On all non-target test plant species on which the larvae developed into pupae, the duration of larval survival was significantly longer than on prickly acacia (Dunn's test, $\mathrm{P}<0.05$; fig. 2). On six of the 17 non-target test plant species (V. sutherlandii F.Muell., A. cardiophylla A. Cunn. ex Benth., A. deanei, A. mearnsii, A. lasiocarpa Benth. and A. conferta A. Cunn. ex Benth.), the rate of successful development (larvae to pupae and larvae to adults) was not significantly different to the target weed (Dunn's test, $\mathrm{P}>0.05$; fig. 3). On the remaining test plant species, the survival rates of larvae and pupae varied greatly, but were significantly lower than on prickly acacia (fig. 3).

\section{No-choice continuation trials}

Phycita sp. completed up to three generations on A. baileyana and at least two generations on $A$. mearnsii, although development time from neonate larva to adult on both species was significantly longer than on prickly acacia (fig. 4). On A. irrorata, Phycita sp. successfully completed one generation, but significantly fewer larvae developed into adults (41 $\pm 13 \%)$ than on prickly acacia $(81 \pm 4 \%) \quad(t=2.76$, $\mathrm{P}=0.05)$. Due to the low number of progeny adults in one of the replicates in the first generation, the second generation trial was not continued. In fecundity trials, fewer fertile eggs were laid by females that developed on $A$. baileyana (64 \pm 29 eggs per female),

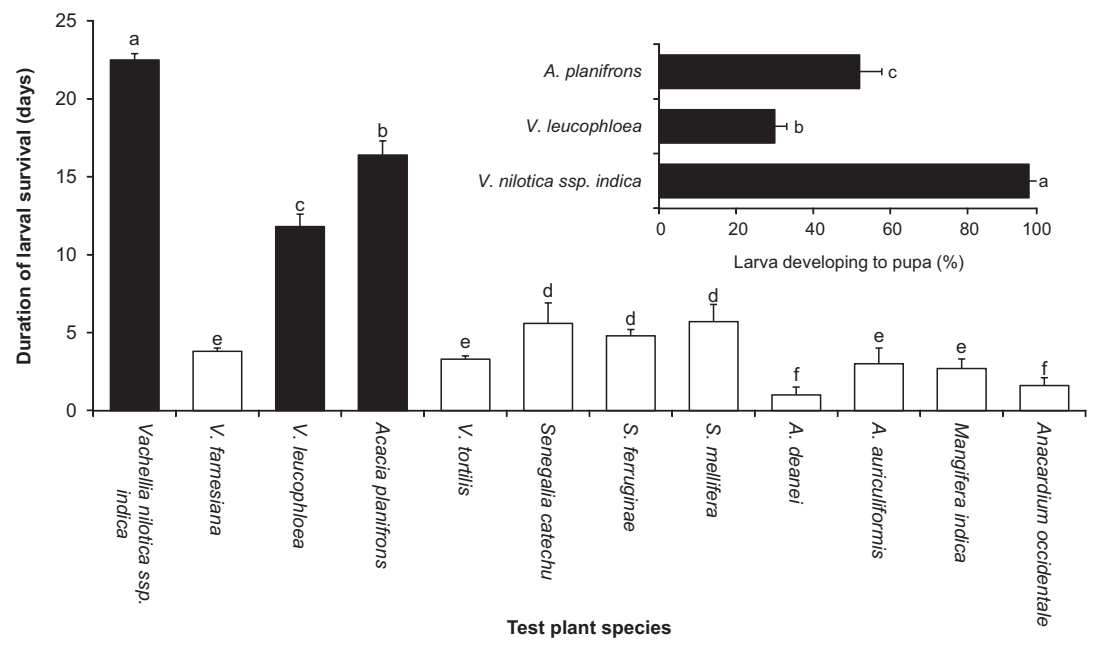

Fig. 1 Duration of larval survival (mean + SE) (main figure) and proportion of larvae developing into pupae (figure in inset) on various test plant species in no-choice tests in India. Solid bars represent test plants on which larvae developed into pupae and the empty bars represent test plants on which no larvae developed into pupae. Means with the same letter are not significantly different (Tukey's test, $P>0.05)$. 
Fig. 2 Duration (mean + SE) of larval (solid bars) and pupal (empty bars) survival on various test plants in no-choice tests under quarantine in Australia. Arrows indicate the test plants on which the larvae did not develop into pupae.

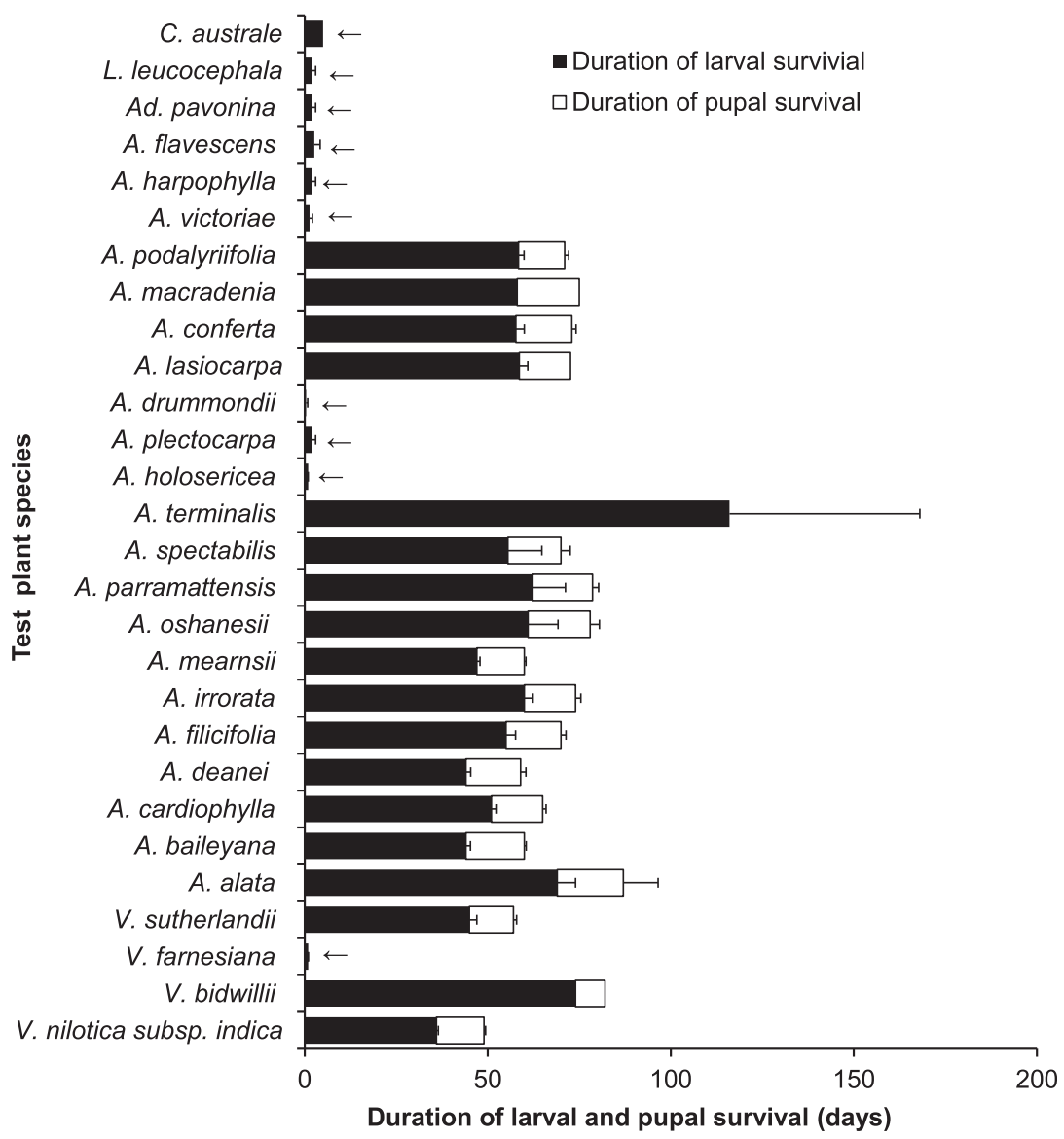

Field host range - India

In India, Phycita sp. was collected from 47 of the 72 survey sites (Table S2). Survey sites with Phycita sp. varied widely between seasons, ranging from 10\% to 55\% (fig. 5). Phycita sp. caused widespread defoliation throughout the year on all three subspecies of $V$. nilotica - in $77 \%$ of the sites with only subsp. indica, in $100 \%$ of the sites with only subsp. cupressiformis, in $61 \%$ of sites with both subsp. indica and subsp. tomentosa and in $67 \%$ of the sites with both subsp. indica and subsp. cupressiformis. Phycita sp. was not observed on $V$. horrida (L.) Kyal. \& Boatwr., V. leucophloea, $S$. ferruginea and $V$. planifrons co-occurring with $V$. nilotica in the field, except for a single collection of Phycita sp. larva on an $V$. planifrons tree at a single site (Ulakkudi kanmai) on one occasion (July 2010) (fig. 5).

\section{Discussion}

In classical weed biological control, potential agents are subjected to host-specificity testing to ensure that the agents are specific to target weeds and there is no risk to non-target plants. This primarily involves no- 


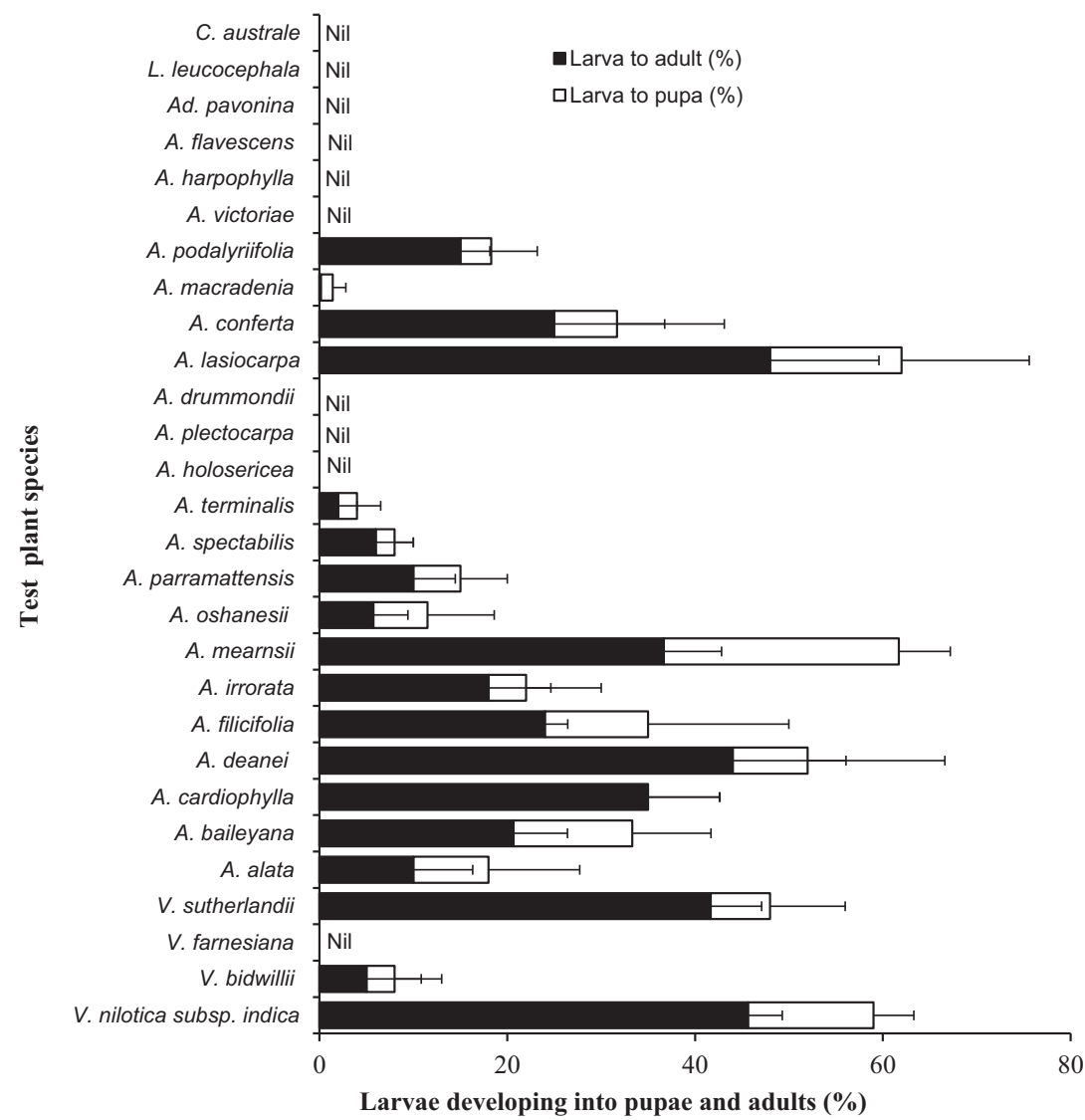

Fig. 3 Proportion (mean $+\mathrm{SE}$ ) of larvae that developed into pupae (empty bars) and adults (solid bars) on various test plant species in nochoice tests under quarantine in Australia. choice tests to predict the fundamental host range (Fowler et al. 2012). When there is non-target feeding and development in no-choice tests, choice tests and no-choice continuation trials are needed to predict the realized host range. Under the current riskaverse regulatory process, any feeding or development on a non-target plant in no-choice tests is often treated as 'risky' (e.g. Dhileepan et al. 2005). This may result in discarding some good agents which are known to have restricted or limited field (realized) host ranges in their native area (Heard 2000; Fowler et al. 2012). Host-specificity test results of Phycita sp. produced contradictory results between the fundamental host range and field host range studies, resulting in its rejection as a biological control agent for prickly acacia.

No-choice larval feeding and development tests were conducted first to determine the fundamental host range of Phycita sp. Under no-choice conditions, Phycita sp. larvae were able to feed and develop on many non-target test plant species. However, on most non-target test plants species, Phycita sp. performed either poorly or not as well as on prickly acacia, as evident from prolonged larval periods and lower rates of successful pupation and adult emergence (figs 1-3). On one of the test plant species (A. deanei), the nochoice larval development tests in India and Australia produced contradictory results - none of the larvae developed into adults in India and 44\% larvae developed into adults in Australia. This was possibly due to difference in the testing methods used, the conditions under which the test plants were grown prior to testing, and the environmental conditions under which the tests were conducted. In India, test plants used were more field-hardened as they were grown under direct sun in the field, while in Australia, the test plants were grown either in a temperature-/humidity-controlled glasshouse or under shade in a greenhouse (with no temperature, humidity and photoperiod control). Also, the tests in India were conducted under natural field conditions including natural sunlight, whereas the tests in Australia were conducted in a quarantine glasshouse under optimum temperature and humidity, but under UV-excluded sunlight. The no-choice host-specificity tests for Phycita sp. in India produced contrasting results to the observed field host range. Although Phycita sp. completed larval development on two non-target test 

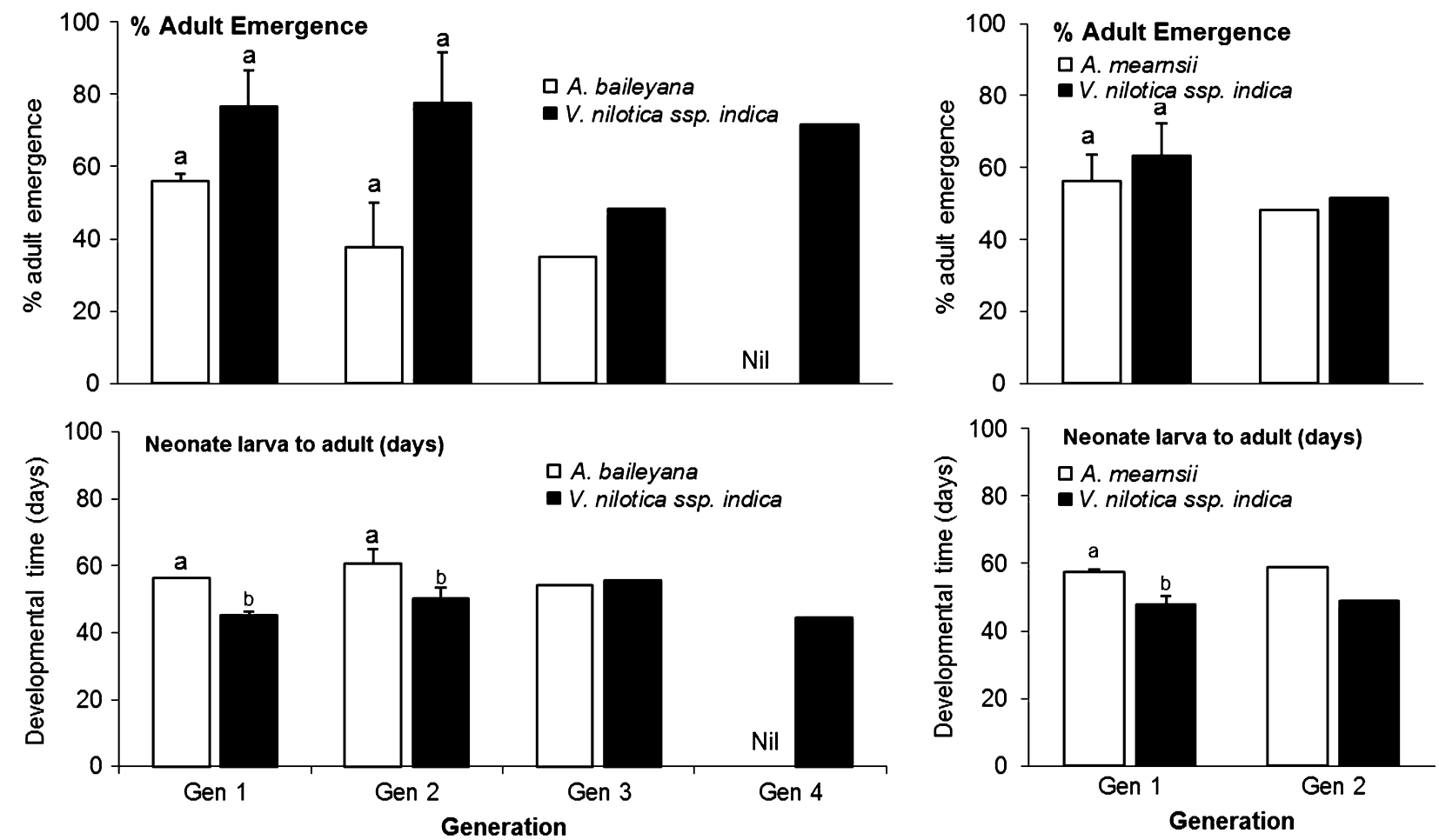

Fig. 4 Durations of larval development (mean + SE) and proportion of larvae that developed into adults (mean + SE) on two non-target test plant species, Acacia mearnsii and A. baileyana (empty bars) and the target weed (solid bars) over multiple generations under no-choice conditions in quarantine in Australia. Within each generation, treatment means with the same letter are not significantly different (Dunn's method, $\mathrm{P}>0.05)$. In the columns where there are no letters, no analyses were performed due to lower number larvae developing on the non-target plant species.

Fig. 5 Incidence (\% of survey sites) of Phycita sp. larvae on Vachellia nilotica (target weed, empty bars) and $V$. planifrons (non-target tree species, solid bar) in relation to season over three years (2008-2011). Phycita sp. was not observed on other non-target tree species (V. horrida, Acacia leucophloea and A. ferruginea) that co-occurred at the survey sites.

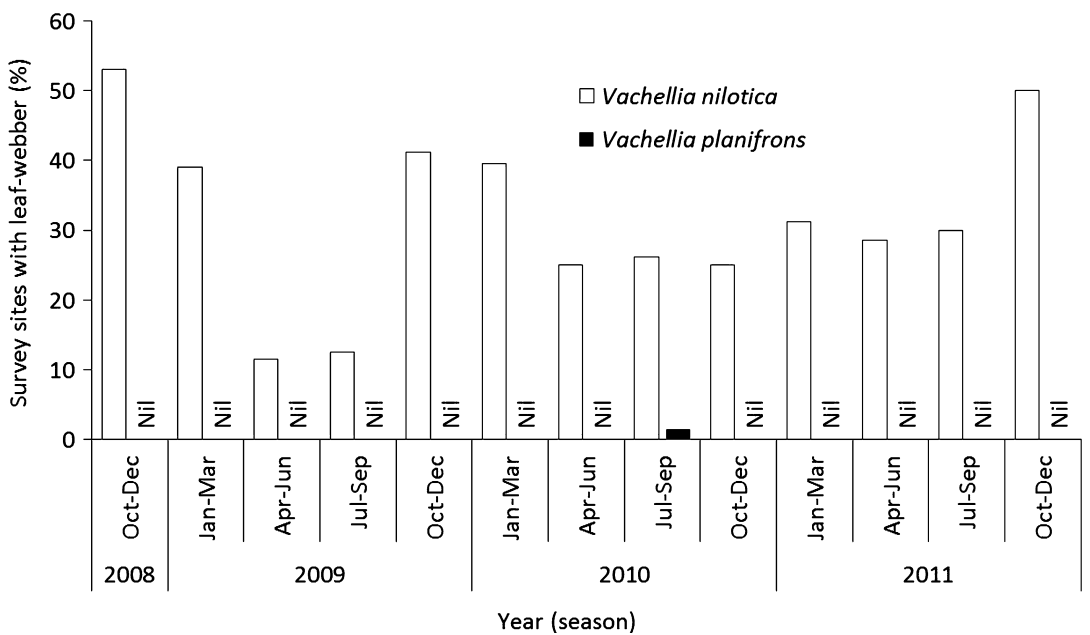

plant species (V. leucophloea and V. planifrons) under no-choice conditions, Phycita sp. larvae were never found on either of the non-target test plant species during field surveys in 72 sites at quarterly intervals over four years (2008-2011), except for a single collection of Phycita sp. larva on an $V$. planifrons tree at a single site (Ulakkudi kanmai) on one occasion (July
2010). Phycita sp. larva was never recovered from $V$. planifrons at this site on subsequent surveys, or in other sites, and hence, V. planifrons cannot be regarded as a natural host for the insect. Many herbivores develop very well in the laboratory on plants that they will not use in nature (e.g. Balciunas et al. 1996; Marohasy 1998; Frye et al. 2010), suggesting 
that field host range is influenced by numerous factors other than host suitability (e.g. Wapshere 1989; Janz et al. 1994; Fox et al. 1996; Sheppard et al. 2005).

In view of larval feeding and development on several non-target test plant species in no-choice tests, subsequent oviposition tests were conducted to predict the realized host range of Phycita sp. No-choice tests are prone to false-positive results, because the 'fundamental' host range is often wider than the field host range and hence may result in the rejection of safe agents (Heard 2000). In Australia, although Phycita sp. completed development on 16 of 27 non-target test plant species in no-choice tests, in paired-choice oviposition trials adults laid eggs only on prickly acacia. However, in paired-choice trials (which were conducted only for three test plant species), only a few eggs were laid, and in some trials, more eggs were laid on the cage walls than on test plants, rendering the results not reliable. In the field in India, Phycita sp. occurred only on prickly acacia, more often on mature prickly acacia trees than on young plants. Host selection mechanisms for Phycita sp. in the field are not known. It is possible that the female moths use the silhouette of prickly acacia trees as cue to locating host trees for oviposition (e.g. Cohen and Brower 1982; Wiklund 1984; Rabasa et al. 2005). Such preference for oviposition on mature trees over young plants has been shown in other lepidopterans (e.g. Thompson and Pellmyr 1991). Upon hatching, the neonate larvae will feed on the same host tree, as the mobility of early larval instars is very limited, with reduced chances of migration between host plants (Zalucki et al. 2002). This suggests that oviposition behaviour could be the key mechanism in host selection of Phycita sp., resulting in its occurrence on only prickly acacia in India.

If host discrimination takes place in different life stages (e.g. oviposition by female moths, feeding by larvae), no-choice discrimination (e.g. oviposition) tests may be the only tests required (e.g. Sheppard et al. 2005). In laboratory and quarantine conditions, the female moths laid more eggs on cage walls and other artificial surfaces than on prickly acacia plants. As a result, no-choice oviposition tests could not be conducted reliably in quarantine. In quarantine tests, the female moths showed a marked preference for oviposition on larger plants than smaller plants, but even when larger plants were offered, fewer eggs were laid than in oviposition containers ( $156 \pm 63$ eggs per female), suggesting that the plant sizes offered in oviposition trials were not suitable for oviposition. Due to limited space availability within quarantine, and logistic difficulties and time required (7 to 10 years) in growing test plants to require size, testing of very large plants/trees of all 16 test plant species that supported development of Phycita sp. was not feasible.

In many lepidopterans, oviposition behaviour, involving long-distance (visual and plant volatile) and short-distance (tactile, chemical stimulants and deterrents) cues are the principal mechanism for host selection in the field (e.g. Thompson and Pellmyr 1991; Keller 1999; Heard 2000; Singer 2004; Stefanescu et al. 2006). Under field conditions, a monophagous insect would search for several days for their preferred host species before accepting a second, less-preferred choice (Singer 2004). In contrast, within a restricted test arena in quarantine, where the test plants were offered directly for oviposition, some of the sequential steps in the natural oviposition behaviour (e.g. longdistance visual and chemical cues) would have been disrupted (e.g. Marohasy 1998; Withers and BartonBrowne 1998; Heard 2000; Singer 2004; Sheppard et al. 2005), making the results unreliable.

The restricted test arena and small size of test plants used in quarantine may have resulted in the indiscriminate oviposition on artificial surfaces (e.g. cage wall) in both no-choice and choice trials. Use of larger, more natural test arenas and open-field testing in the native range may alleviate this problem (Balciunas et al. 1996; Briese 1999; Heard 2000; Frye et al. 2010). As the field observations suggest that the female moth laid eggs on mature trees, any choice trial in India should be conducted using fully grown Australian native test plant species on which the larvae completed development in no-choice tests under quarantine conditions in Australia. As this is not practical, further screening of other test plants was suspended, the insect was not considered further as a biocontrol agent for prickly acacia in Australia, and the colony in quarantine was destroyed.

\section{Acknowledgements}

We thank M. Senthilkumar and R. Mahalakshimi (Institute of Forest Genetics and Tree Breeding, Coimbatore, Tamil Nadu, India) for technical support; the Director of the Institute of Forest Genetics $\delta$ Tree Breeding (Coimbatore, Tamil Nadu, India) for the facilities; George Mathew (Kerala Forest Research Institute, India), Thomas Simonsen and Kevin Tuck (NHM, UK) for their help with the identification of the moth; Tony Pople, Joe Scanlan and two anonymous reviewers for comments on earlier versions of the manuscript; and Meat 8 Livestock Australia and Rural Industries Research and Development Corporation for funding the study. 


\section{References}

Aina JO, 1983. Phycita melongenae sp. n (Lepidoptera: Pyralidae) associated with eggplant in West Africa. Bull Entomol Res, 73, 427-429.

Balciunas JK, Burrows DW, Purcell MF, 1996. Comparison of the physiological and realized host-ranges of a biological control agent from Australia for the control of the aquatic weed, Hydrilla verticillata. Biol Control, 7, 148158.

Brenan JPM, 1983. Manual of taxonomy of Acacia species. Present taxonomy of four species of Acacia (A. albida, A senegal, A nilotica, A tortilis). Food and Agricultural Organisation of the United Nationals, Rome, Italy, 47.

Briese DT, 1999. Open field host-specificity tests: is "natural" good enough for risk assessment? In: Host specificity testing in Australasia: towards improved assays for biological control. Ed. by Withers TM, Barton Browne L, Stanley J. Scientific Publications, QLD DNR, Coorparoo, Australia, 44-59.

Brues CT, 1936. Aberrant feeding behaviour among insects and its bearing on the development of specialized food habits. Q Rev Biol, 11, 305-319.

Butani DK, 1970. Insect pests of cotton-western herbaceum region of India. PANS, 16, 56-64.

Cohen JA, Brower LP, 1982. Oviposition and larval success of wild monarch butterflies (Lepidoptera: Danaidae) in relation to host plant size and cardenolide concentration. J Kans Entomol Soc, 55, 343-348.

Coombs EM, Clark JK, Piper GL, Cofrancesco AF (Eds), 2004. Biological control of invasive plants in the United States. Oregon State University Press, Corvallis, 146.

Dhileepan K, 2009. Acacia nilotica ssp. indica (L.) Willd. ex Del. (Mimosaceae). In: Biological control of tropical weeds using arthropods. Ed. by Muniappan R, Reddy GVP, Raman A. Cambridge University Press, UK, 17-37.

Dhileepan K, Trevino M, Donnelly GP, Raghu S, 2005.

Risk to non-target plants from Charidotis auroguttata (Chrysomelidae: Coleoptera), a potential biocontrol agent for cat's claw creeper Macfadyena unguis-cati (Bignoniaceae) in Australia. Biol Control, 32, 450-460.

Dhileepan K, Wilmot KADW, Raghu S, 2006. A systematic approach to biological control agent exploration and selection for prickly acacia (Acacia nilotica ssp. indica). Aust J Entomol, 45, 302-306.

Dhileepan K, Lockett C, Robinson M, Pukallus K, 2009. Prioritising potential guilds of specialist herbivores as biological control agents for prickly acacia through simulated herbivory. Ann Appl Biol, 154, 97-105.

Dhileepan K, Balu A, Ahmed SI, Singh S, Srivastava KK, Senthilkumar M, Murugesan S, Senthilkumar P, Gorain M, Sharma A, Sharma N, Mahalakshmi R, Shivas R, 2010. New biological control opportunities for prickly acacia: exploration in India. In: Proceedings of the 17th Australasian Weeds Conference. Ed. by Zydembos SM,
New Zealand Plant Protection Society, Christchurch, New Zealand, 231-234.

Dhileepan K, Balu A, Senthilkumar P, Murugesan M, Shivas $\mathrm{R}, 2013$. Survey and prioritisation of potential biological control agents for prickly acacia (Acacia nilotica ssp. indica) from southern India. Biocontrol Sci Technol, 23, 646-664.

Dhileepan K, Taylor DBJ, Lockett CJ, Balu A, Seier MK, Murugesan S, Tanner RA, Pollard KM, Kumaran N, Neser S, 2014. Biological control of prickly acacia (Vachellia nilotica subsp. indica): current research and future prospects. In: Proceedings of the XIV International Symposium of Biological Control of Weeds. Ed. by Impson FAC, Kleinjan CA, Hoffmann JF. University of Cape Town, South Africa, 21-30.

Dodd AP, 1940. The biological control campaign against prickly-pear. Commonwealth Prickly Pear Board, Brisbane, QLD, Australia, 177.

Dwivedi AP, 1993. Babul (Acacia nilotica): a multipurpose tree of dry areas. Arid Forest Research Institute, Indian Council of Forestry Research and Education, Jodhpur, India, 226.

Fowler SV, Paynter Q, Dodd S, Groenteman R, 2012. How can ecologists help practitioners minimise non-target effects in weed biocontrol? J Appl Ecol, 49, 307-310.

Fox CW, Harbin AD, Mousseau TA, 1996. Suitability of a non-host Palo Verde for development of Stator limbatus (Horn) (Coleoptera: Bruchidae) larvae. Pan-Pac Entomol, 72, 31-36.

Frye MJ, Lake EC, Hough-Goldstein J, 2010. Field hostspecificity of the mile-a-minute weevil, Rhinoncomimus latipes Korotyaev (Coleoptera: Curculionidae). Biol Control, 55, 234-240.

Heard TA, 2000. Concepts in insect host-plant selection behaviour and their application to host specificity testing. In: Proceedings of session: Host-Specificity Testing of Exotic Arthropod Biological Control Agents - the Biological Basis for Improvement in Safety. Ed. by Van Driesche RG, Heard TA, McClay A, Reardon R. USDA Forest Service, Forest Health Technology Enterprise Team, Morgantown, 1-10.

Hutson JC, 1939. Report on the work of the Entomological Division. Administration Report Director of Agricultural Ceylon, D36-D41.

Janz N, Nylin S, Wedell N, 1994. Host plant utilization in the comma butterfly: source of variation and evolutionary implications. Oecologia, 99, 132-140.

Keller MA, 1999. Understanding host selection behaviour: the key to more effective host specificity testing. In: Host specificity testing in Australasia: towards improved assays for biological control. Ed. by Withers TM, Barton-Browne L, Stanley J. Queensland Department of Natural Resources, Brisbane, Australia, 84-92.

Kodela PG, Wilson PG, 2006. New combinations in the genus Vachellia (Fabaceae: Mimosoideae) from Australia. Telopea, 11, 233-244. 
Kriticos D, Brown J, Radford I, Nicholas M, 1999. Plant population ecology and biological control: Acacia nilotica as a case study. Biol Control, 16, 230-239.

Kriticos DJ, Sutherst RW, Brown JR, Adkins SW, Maywald GF, 2003. Climate change and the potential distribution of an invasive alien plant: Acacia nilotica ssp. indica in Australia. J Appl Ecol, 40, 111-124.

Mackey AP, 1997. The biology of Australian weeds 29. Acacia nilotica ssp. indica (Benth.) Brenan. Plant Prot Q, 12, 7-17.

Marohasy J, 1992. Biocontrol of Acacia nilotica using insects from Kenya. Final Report to Australian Wool Corporation. Alan Fletcher Research Station, Queensland Department of Lands, 75.

Marohasy J, 1998. The design and interpretation of hostspecificity tests for weed biological control with particular reference to insect behaviour. Biocontrol News Inform, 19, 13N-20N.

Maslin BR, 2001. Introduction to Acacia. In: Flora of Australia. Volume 11A, Mimosaceae, Acacia part 1. Ed. by Orchard AE, Wilson AJG, Australian Biological Resources Study (ABRS), Canberra, and CSIRO Publishing, Melbourne, 3-13.

Mohyuddin AI, 1986. Investigations on the natural enemies of Acacia nilotica in Pakistan. Final Report, Commonwealth Institute of Biological Control, Rawalpindi, Pakistan, 116.

Orchard AE, Maslin BR, 2003. Proposal to conserve the name Acacia (Leguminosae: Mimosoideae) with a conserved type. Taxon, 52, 362-363.

Orchard AE, Wilson AJG (Eds), 2001. Flora of Australia, volumes 11A \& 11B, Mimosaceae, Acacia, Parts 1 \& 2. Australian Biological Resources Study (ABRS), Canberra, and CSIRO Publishing, Melbourne.

Palmer WA, Lockett CJ, Senaratne KADW, McLennan A, 2007. The introduction and release of Chiasmia inconspic$u a$ and $C$. assimilis (Lepidoptera: Geometridae) for the biological control of Acacia nilotica in Australia. Biol Control, 41, 368-378.

Ponnuswami MK, 1971. Hyalospilla leuconeurella, a new mango borer in Tiruchirapalli and its control. Plant Prot Bull India, 23, 38-39.

Rabasa SG, Gutiérrez D, Escudero A, 2005. Egg-laying by a butterfly on a fragmented host plant: a multi-level approach. Ecography, 28, 629-639.

Radford IJ, Nicholas DM, Brown JR, 2001. Assessment of biological control impact of seed predators on the invasive shrub Acacia nilotica (Prickly acacia) in Australia. Biol Control, 20, 261-268.

Ram S, Pathak KA, 1987. Record on insect pests of fibre crop (cotton) in Manipur. Bull Entomol, 28, 6970.

Rani BJ, Sridhar V, 2002. Record of insect pests of Jatropha, Jatropha curcas Linn. - a medicinal and minor oil seed plant. Insect Environ, 8, 76-77.
Sakalasooriya MB, Wijayagunasekara HNP, Marambe B, Shaw R, 2000. Identification of potential biological control agents for Ligustrum robustum ssp. walkeri. Trop Agric Res, 12, 205-216.

Sheppard AW, van Klinken RD, Heard TA, 2005. Scientific advances in the analysis of direct risks of weed biological control agents to non-target plants. Biol Control, 35 , 215-226.

Singer MC, 2004. Oviposition preference: its definition, measurement, correlates and its use in assessing risk of host shifts. In: Proceedings of the XI International Symposium on Biological Control of Weeds. Ed. by Cullen JM, Briese DT, Kriticos DJ, Lonsdale WM, Morin L, Scott JK. CSIRO Entomology, Canberra, 235244.

Spies P, March N (Eds), 2004. Prickly acacia national case studies manual: approaches to the management of prickly acacia (Acacia nilotica subsp. indica) in Australia. Department of Natural Resources, Mines and Energy, Brisbane, Australia.

Stals R, 1997. A survey of phytophagous organisms associated with Acacia nilotica in South Africa. Final Report to the Queensland Department of Natural Resources. ARCPlant Protection Research Institute, Pretoria, South Africa, 113.

Stefanescu C, Jubany J, Dantart J, 2006. Egg-laying by the butterfly Iphiclides podalirius (Lepidoptera, Papilionidae) on alien plants: a broadening of host range or oviposition mistake? Anim Biodivers Conserv, 29, 83-90.

Thompson JN, Pellmyr O, 1991. Evolution of oviposition behaviour and host preference in Lepidoptera. Annu Rev Entomol, 36, 65-98.

Wapshere AJ, 1989. A testing sequence for reducing rejection of potential biological control agents for weeds. Ann Appl Biol, 114, 515-526.

Wardill TJ, Graham GC, Zalucki MP, Palmer WA, Playford $\mathrm{J}$, Scott KD, 2005. The importance of species identity in the biocontrol process: identifying the subspecies of Acacia nilotica (Leguminosae: Mimosoideae) by genetic distance and their implications for biological control. J Biogeogr, 32, 2145-2159.

Wiklund C, 1984. Egg-laying patterns in butterflies in relation to their phenology and the visual apparency and abundance of their host plants. Oecologia, 63, 23-29.

Withers TM, Barton-Browne L, 1998. Possible causes of apparently indiscriminate oviposition in host specificity tests using phytophagous insects. In: Proceedings of the 6th Australasian Applied Entomological Research Conference. Ed. by Zalucki M, Drew R, White G, University of Queensland, Brisbane, 565-571.

Zalucki MP, Clarke AR, Malcolm SB, 2002. Ecology and behaviour of first instar larval Lepidoptera. Annu Rev Entomol, 47, 361-393. 


\section{Supporting Information}

Additional Supporting Information may be found in the online version of this article:
Table S1. List of test plant species used in host specificity test with Phycita sp. in Australia and India.

Table S2. Survey sites in Tamil Nadu and Karnataka states in India. 